\title{
Analysis of tourism potential and the community perception in buffer village to support tourism development of Alas Purwo National Park
}

\author{
M Habibi Yadi Irawanata ${ }^{\mathrm{a}}$, Baba Barus ${ }^{\mathrm{b}}$, Nandi Kosmaryandi ${ }^{\mathrm{c}}$ \\ ${ }^{a}$ Graduate School Regional Planning Study Program, IPB University, Darmaga Campus IPB Bogor, 16680, Indonesia \\ [+62 82243373868] \\ ${ }^{\mathrm{b}}$ Department of Soil Science and Land Resources, Faculty of Agriculture, IPB University, Darmaga Campus IPB Bogor, 16680, \\ Indonesia \\ ${ }^{\mathrm{c}}$ Department of Forest Resources Conservation and Ecotourism, Faculty of Forestry, IPB University, Darmaga Campus IPB Bogor, \\ 16680 , Indonesia
}

Article Info:

Received: 03 - $05-2021$

Accepted: $02-08-2021$

Keywords:

Buffer village, perceptions

community, potential tourism, the national park

Corresponding Author:

M Habibi Yadi Irawanata, Regional Planning Science,

Graduate School, Bogor

Agricultural University;

Tel. +6282243373868

Email:

mhabibiyadi8@gmail.com

\begin{abstract}
The Indonesian Government designated the TNAP area as a National Tourism Development Area (KPPN). The determination of the TNAP area as a tourist attraction at the national level opens opportunities and is a driving force for the development of TNAP buffer villages. The potential development of a buffer village is community empowerment by utilizing potential resources, for example, tourism potential. The development of a buffer village as a tourist area requires community support. This study aims to analyze the potential of tourism in the TNAP buffer village and determine the community's perception of tourism development. The analysis results show that the TNAP buffer village has decent resource potential to be developed as a tourist object and attraction. Some villages have ODTW potential, including four villages that have the potential for tourism development. Tourism development must provide space for the community to participate in tourism management. The results of the community perception assessment illustrate that the community agrees with tourism development. Communities involved in tourism development can respond positively to support tourism development activities.
\end{abstract}

How to cite (CSE Style $8^{\text {th }}$ Edition):

Irawanata MHY, Barus B, Kosmaryandi N. 2021. Analysis of tourism potential and the community perception in buffer village to support tourism development of Alas Purwo National Park. JPSL 11(3): 350-362. http://dx.doi.org/10.29244/jpsl.11.3.350-362.

\section{INTRODUCTION}

The Regional Medium-Term Development Plan (RPJMD) of Banyuwangi Regency is developing the region's leading sectors, one of which is the tourism sector. The Banyuwangi Regency Government makes the tourism sector a leading development sector and pays great attention to the development of tourism potential in each region (PKB, 2017). The development of the Banyuwangi Regency is based on the Indonesian Government's tourism plan, establishing the Alas Purwo National Park (TNAP) area as a National Tourism Development Area (KPPN) and a leading tourist area.

Over time, the TNAP area, which was declared as KPPN, is still experiencing pressure and threats caused by the excess and illegal activities of the buffer village community towards the use of resources in the TNAP area as well as the expansion of land use by the community (Balai TNAP, 2015). Report Based on the Balai TNAP (2015), threats that occur in the TNAP area include taking animals and flora, which are tourist attractions in the TNAP area. 
The sustainability of the TNAP area as a tourist attraction can be influenced by the activities and interactions of the community around the national park. To reduce and cause the emergence of the TNAP area as a tourist attraction, a strategy is needed to deal with this problem, one of which is through community empowerment. Based on the Regulation of the Minister of Environment and Forestry No. 43 of 2017 concerning Community Empowerment Around Nature Reserve Areas and Nature Conservation Areas that community empowerment aims to develop the independence and welfare of communities around conservation areas to support conservation by increasing knowledge, attitudes, skills, behavior, abilities and awareness as well as utilizing existing resources. Efforts to empower the TNAP buffer village community that can be carried out are the use of existing resources as a tourist attraction.

The determination of the TNAP area as a national-level tourist attraction opens opportunities and drives village development and supports community empowerment through tourism development in TNAP buffer villages. Based on the Regulation of the Minister of Culture and Tourism Number 18 of 2013 (Kemenbudpar) concerning Guidelines for the National Community Empowerment Program (PNPM) Mandiri Tourism, the designation of an area as a tourist attraction can provide benefits and linkages with the surrounding area both as a tourist attraction and supporting tourism activities.

Based on the description above, this research was conducted to determine the potential in the TNAP buffer village that can be developed as a tourist object and attraction. Tourism development in the TNAP buffer village is how the sector can reduce community pressure on the use of resources in the TNAP area and increase community welfare and become an alternative economic source for the community at this time without reducing the potential use of natural resources in the future. According to Buditiawan and Harmono (2020), tourism development has an essential role in regional development and opens or adds fields and job opportunities for communities around tourist areas. Tourism development in the buffer village is expected to be a supporting supporter to provide a diversity of species and increase the competitiveness of tourism development in KPPN TNAP.

The potential development of the TNAP buffer village as a tourist area will be constrained if the lack of support and community involvement is known through public perception. Community perception is important because it describes how much community support for tourism development and becomes an opportunity for community empowerment in activities directly related to tourism and reducing conflicts that can occur in the future. Community support for tourism development is a driving factor for tourism development. According to Yoon and Uysal (2003) in Prameswari et al. (2018), tourism activities, in general, can occur due to push factors and pull factors so that these factors can provide satisfaction for tourists. Based on the description above, this study aims to analyze the tourism potential in the TNAP buffer village and determine the community's perception of the buffer village.

\section{METHOD}

\section{Study Area and Time Research}

This research was conducted from July to October 2020. The research locations are in 12 buffer villages in Muncar, Tegaldlimo, and Purwoharjo Districts, Banyuwangi Regency. The determination of the buffer village is based on a report by the Balai TNAP (2014), and information from the TNAP Balai and more details can be seen in Figure 1. 


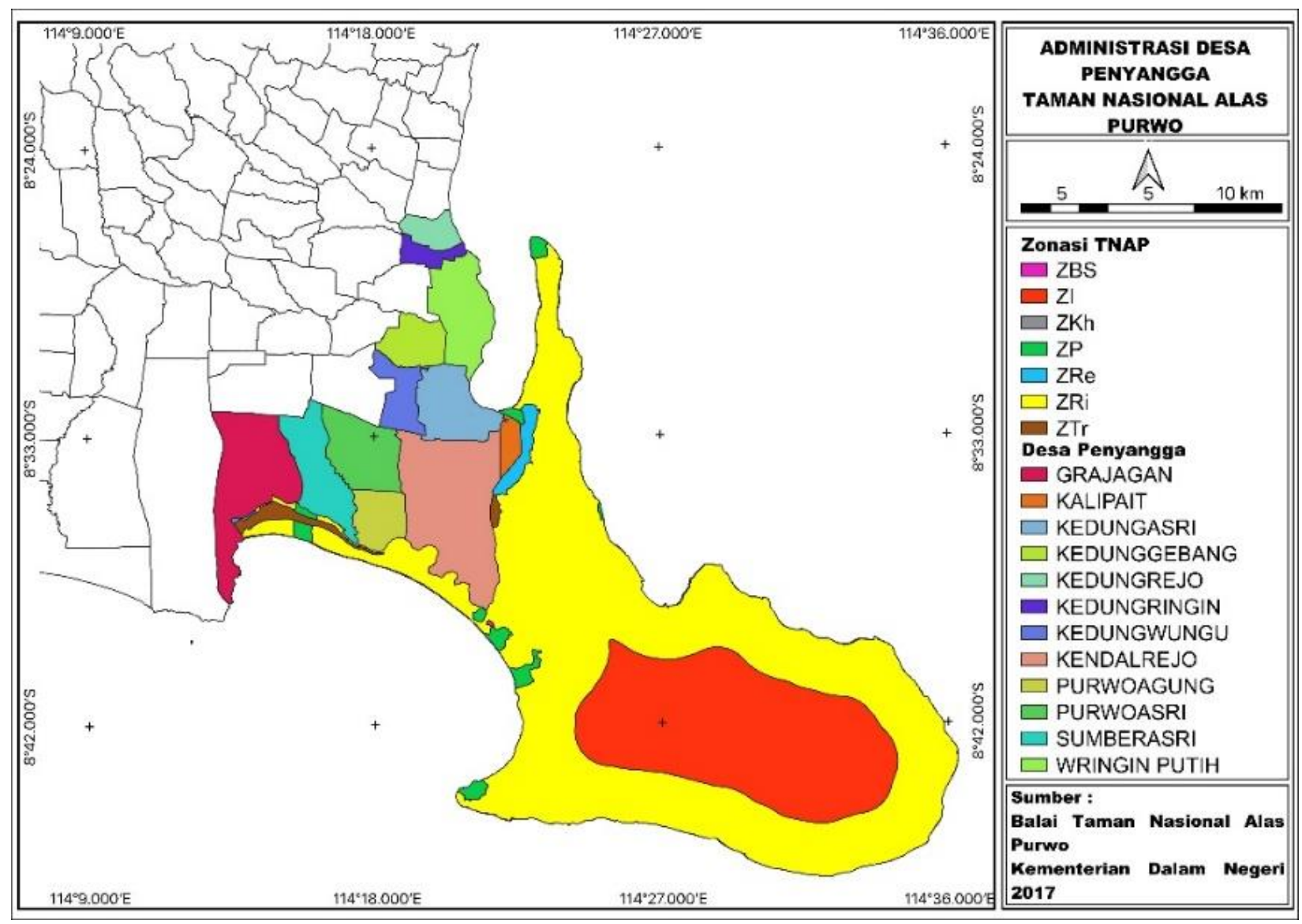

Figure 1 Study area

\section{Method of Collecting Data}

The data used in this study are primary data and secondary data. Primary data is obtained through interviews and field observations, while secondary data is obtained from literature studies and related agencies. Primary data in the form of observation of potential tourist attraction objects (ODTW) and questionnaires on public perceptions of tourism development, while the secondary data used are documents for the development of the TNAP area, RTRW, RPJMD, RIPKD Banyuwangi Regency. The data collection and data analysis matrix include the type and weight of the assessment, data collection methods, and data analysis techniques, and the expected outputs in the study are presented in Table 1.

Data collection on public perception was conducted using questionnaires and interviews. Questionnaires were used to obtain data related to perceptions of tourism development, while interviews were conducted to explore the information obtained from the questionnaires and to determine community involvement in tourism development. The selection of community respondents was carried out using purposive sampling, which means that the sampling method was carried out with a purpose. Respondents include heads of families, business owners, housewives, and teenagers considering that this community group will play a role and be involved in tourism development, both as tourism managers and supporting tourism activities. Community respondents were taken from 12 buffer villages with 100 respondents from 117298 people or $10 \%$ of the total number of respondents. According to Arikunto (2006), the number of respondents is set at $10-15 \%$ of the total respondents. The number of respondents from each village is determined proportionally based on the number of residents of each village with the number of respondents in each village between 3 23 respondents. 
Table 1 Matrix of assessment types, data collection, data analysis, and expected output

\begin{tabular}{|c|c|c|c|c|}
\hline No & Rating Type & $\begin{array}{l}\text { Collection } \\
\text { Method }\end{array}$ & $\begin{array}{c}\text { Analysis } \\
\text { Techniques }\end{array}$ & $\begin{array}{l}\text { Expected } \\
\text { Output }\end{array}$ \\
\hline 1 & $\begin{array}{l}\text { Tourist Attractions (ADO-ODTW Guidelines) } \\
\text { The attraction of Tourism Objects: uniqueness } \\
\text { of resources, many prominent natural } \\
\text { potentials, tourist activities that can be carried } \\
\text { out, cleanliness, comfort, and security of the } \\
\text { area }\end{array}$ & & $\begin{array}{l}\mathrm{S}=\mathrm{N} \times \mathrm{B} \\
\text { Information: }\end{array}$ & \\
\hline 2 & $\begin{array}{l}\text { Supporting Elements (ADO-ODTW } \\
\text { Guidelines) } \\
\text { a. Accessibility: Road conditions, road } \\
\text { type, distance from the city center, and travel } \\
\text { time from the city center } \\
\text { b. Accommodation: Number of rooms and } \\
\text { number of accommodation } \\
\text { c. Supporting infrastructure and facilities } \\
\text { d. Availability of clean water: volume, whether } \\
\text { or not water can be drained, suitability for } \\
\text { consumption, and availability }\end{array}$ & $\begin{array}{l}\text { Literature } \\
\text { Study, } \\
\text { Interview, } \\
\text { and Field } \\
\text { Observation }\end{array}$ & $\begin{array}{l}\mathrm{S}: \text { score/score } \\
\mathrm{N} \text { : the sum of } \\
\text { the values of the } \\
\text { elements in the } \\
\text { criteria } \\
\mathrm{B} \text { : value weight }\end{array}$ & $\begin{array}{l}\text { Decent tourism } \\
\text { potential to be } \\
\text { developed in } \\
\text { the buffer } \\
\text { village }\end{array}$ \\
\hline 3 & $\begin{array}{l}\text { Perception of community for tourism } \\
\text { development }\end{array}$ & $\begin{array}{l}\text { Questionnaire } \\
\text { and interview }\end{array}$ & Likert scale & $\begin{array}{l}\text { Perception of } \\
\text { community for } \\
\text { tourism } \\
\text { development }\end{array}$ \\
\hline
\end{tabular}

\section{Analysis Method}

\section{Tourism Potential Assessment}

The assessment analysis used is the analysis of potential objects and tourist attractions (ODTW) based on modifying the ADO-ODTW analysis guidelines set by the Director-General of Forest Protection and Nature Conservation/Dirjen PHKA (2003). The assessment is carried out as an effort for a region to develop tourism potential and provide the feasibility of an ODTW being developed as a tourist attraction. The results of the assessment of tourism potential in the buffer village are described descriptively. The results of the assessment are calculated using the following equation :

\section{Description:}

$$
\mathrm{S}=\mathrm{N} \times \mathrm{B}
$$

$\mathrm{S}$ : score; $\mathrm{N}$ : the sum of the values of the elements in the criteria; B: value weight

The results of the ODTW assessment and supporting elements in each buffer village were then classified based on the total number of ODTW assessments and supporting elements, ranging from very potential (SP), potential (P), and less potential (KP) classes. Determination of class eagles is calculated using the following equation:

$$
\text { Hose }=\frac{\operatorname{Smax}-\operatorname{Smin}}{\mathrm{K}}
$$

Description:

Hose: the value of the interval in the determination of the assessment classification interval; Smax: the highest score; K: the number of assessment classifications; Smin: lowest score. 


\section{Community Perception Assessment}

Assessment of community perceptions of tourism development in TNAP buffer villages using a Likert scale. The use of the Likert Scale is because several questions can form a score/value that represents the respondent's attitude to provide an answer to how the respondent's perception of development. The results of the community perception assessment were tabulated and analyzed descriptively. The assessment of public perception was then classified based on the attitude of the respondents towards tourism development, starting from strongly agree, agree, doubtful, less agree, and strongly disagree.

\section{RESULTS AND DISCUSSION}

\section{Assessment of Potential Objects and Tourist Attractions}

Alas Purwo National Park (TNAP) is a conservation area with ecosystems typical of various types of ecosystems such as coastal forests, lowland forests, mangrove forests, and bamboo forests. The diversity of ecosystems in the TNAP area makes the TNAP area has 26 species of mangroves, 13 species of bamboo, and 21 species of grass, as well as 50 species of mammals, 320 species of birds, 15 species of amphibians, and 48 species of reptiles (Balai TNAP, 2014). The TNAP area, which has various resources, is a leading tourist area used as a driving force for tourism in Banyuwangi Regency and is expected to grow the tourist areas around it synergistically (PKB, 2016).

In line with the development of tourism in the TNAP area, the development of tourism in the buffer village as supporting tourism is considered very strategic to support the KPPN TNAP and improve the economy of the buffer village area and the welfare of the community. Rural areas are areas where various natural, social, and cultural resources can be utilized as tourist attractions. To develop a buffer village as a tourist area, an assessment of the potential resources that are potential and feasible to be developed is needed. The results of the assessment of potential objects and tourist attractions (ODTW) in the buffer villages are presented in Table 2.

Table 2 Potential objects and tourist attractions in buffer villages

\begin{tabular}{clccccccc}
\hline \multirow{2}{*}{ No } & \multirow{2}{*}{ Village } & \multicolumn{7}{c}{ Assessment Element } \\
\cline { 3 - 8 } & 1 & 2 & 3 & 4 & 5 & Amount & Classification \\
\hline 1 & Wringinputih & 660 & 450 & 60 & 180 & 630 & 1930 & $\mathrm{SP}$ \\
2 & Kedungrejo & 480 & 475 & 60 & 180 & 630 & 1825 & $\mathrm{KP}$ \\
3 & Kedungasri & 660 & 400 & 60 & 180 & 630 & 1930 & $\mathrm{P}$ \\
4 & Kedunggebang & 550 & 450 & 60 & 180 & 630 & 1870 & $\mathrm{KP}$ \\
5 & Kedungwungu & 510 & 475 & 60 & 180 & 630 & 1855 & $\mathrm{KP}$ \\
6 & Kendalrejo & 570 & 400 & 60 & 180 & 630 & 1840 & $\mathrm{KP}$ \\
7 & Sumberasri & 660 & 450 & 60 & 165 & 630 & 1965 & $\mathrm{SP}$ \\
8 & Grajagan & 720 & 425 & 60 & 165 & 630 & 2000 & $\mathrm{SP}$ \\
9 & Kedungringin & - & - & - & - & - & - & - \\
10 & Kalipait & - & - & - & - & - & - & - \\
11 & Purwoasri & - & - & - & - & - & - & - \\
12 & Purwoagung & - & - & - & - & - & - & - \\
\hline
\end{tabular}

Information: SP: very potential (>1 942-2 000); P: potential (>1 883-1 942); KP: less potential (1 825-1 883); 1. attractiveness; 2. accessibility; 3. accommodation; 4. infrastructure; 5. clean water

The analysis results show that the TNAP buffer villages with a score of $1825-2000$ are villages with decent resource potential to be developed as tourist objects and attractions. Villages that have ODTW potential, which is included in the very potential category (SP) are 3 villages, the potential category $(\mathrm{P})$ is 1 
village, the less potential category (KP) is 4 villages and 4 villages do not have ODTW potential. Villages that do not have tourism potential are due to the absence of resources that can be developed as ODTW and the lack of the Village Government to develop artificial tourism by the village area, and some villages have resources, but the Village Government does not optimize the use of existing resources to be developed as tourism. Villages that are included in the SP category are villages that have a diverse potential for ODTW and are supported by good and complete supporting elements. Buffer villages included in the potential category have ODTW potential but have not been supported by good and complete supporting elements. They need to be improved by adding supporting infrastructure facilities that support tourism development. Meanwhile, for villages that are categorized as having less potential, it is necessary to optimize the existing potential and explore new tourism potential, and it is necessary to increase the availability of tourism supporting infrastructure.

The diversity of the potential of ODTW in the buffer village is formed naturally, such as landscape forms, natural panoramas, and forests, as well as artificially from people's lives such as temples. Development of tourism potential in buffer villages to strengthen regional development activities and support community empowerment programs. In addition, the development of tourism potential in TNAP buffer villages can act as a supporting or alternative tourist attraction to support KPPN TNAP. Through tourism development in buffer villages, tourism development in the TNAP area will have a diversity or diversification of types of tourism that will open up opportunities to bring in tourists.

The development of tourism in the buffer village can be used as an optimization of the utilization of the village's local potential, which can encourage the growth and development of the socio-cultural and economic fields of the community. The existence of tourism in the buffer village is expected to preserve the culture and local wisdom that exists in the community and can increase public awareness of environmental sustainability both in national parks and villages. Tourism development can be key in maintaining and conserving the biodiversity of an area, providing long-term economic benefits for the community, reducing poverty, and preserving cultural heritage values and customs, and contributing to increased tolerance and understanding between cultures (Hamzah and Irfan, 2018).

\section{Tourism Attraction}

A tourist attraction is an object with uniqueness, beauty, and diversity of resources which are factors of interest for tourists to visit. Tourist attractions include the uniqueness of natural resources, types of tourism activities or activities, cleanliness of tourist objects, and the comfort and safety of tourist objects. The tourist attraction in the buffer village has a value that shows whether or not a tourist attraction is developed and how strong it can attract tourists to visit. The assessment of the components of tourist attractions in the buffer village is presented in Table 3.

Based on the results of field observations, the potential tourist attraction in the TNAP buffer village is in the form of the potential attractiveness of natural resources such as beach tourism objects, mangrove forest ecosystems, and socio-cultural wealth. The coastal area in the buffer village is one of the areas planned for tourism development in East Java Province and Banyuwangi Regency and a coastal area with a wide coastline and panoramic views and beautiful cliffs around the coast. The mangrove forest area in the TNAP buffer village becomes a barrier between land and sea, and there are at least twelve types of mangroves (BBKSDA East Java, 2018). The diversity of mangroves is an invaluable potential, and this mangrove area is a habitat for wild animals, especially birds, marine animals, and mammals. In addition, the TNAP buffer villages have various socio-cultural attractions such as buildings for religious activities (temples and caves) and various ceremonies that are often performed by the community (sea picking ceremony). The temples and caves in the buffer village are not too big but are often used as places to worship and have beautiful landscape views around the forest. Ceremonies carried out in the buffer village, such as the sea picking ceremony, are carried out by fishing communities in Muncar District in the month of Muharram. The fishing 
community in the buffer village still adheres to this tradition because it symbolizes gratitude for the fishing community to God Almighty and as a repellent to reinforcements. The diversity of tourist attractions in the TNAP buffer village is a potential that can be developed into tourism that can bring in tourists. According to Yuniarti et al. (2018), the diversity of tourist attractions and existing tourism activities is a potential that significantly determines the level of tourist visits to a tourist attraction.

Table 3 Assessment of tourist attraction components

\begin{tabular}{clccccccc}
\hline \multirow{2}{*}{ No } & \multirow{2}{*}{ Village } & \multicolumn{7}{c}{ Tourist Attraction Assessment Elements } \\
\cline { 3 - 9 } & & 1 & 2 & 3 & 4 & Score & Weight & Total \\
\hline 1 & Wringinputih & 25 & 25 & 30 & 30 & 110 & 6 & 660 \\
2 & Kedungrejo & 10 & 10 & 30 & 30 & 80 & 6 & 480 \\
3 & Kedungasri & 25 & 25 & 30 & 30 & 110 & 6 & 660 \\
4 & Kedunggebang & 15 & 15 & 30 & 30 & 90 & 6 & 550 \\
5 & Kedungwungu & 10 & 15 & 30 & 30 & 85 & 6 & 510 \\
6 & Kendalrejo & 15 & 20 & 30 & 30 & 95 & 6 & 570 \\
7 & Sumberasri & 25 & 25 & 30 & 30 & 110 & 6 & 660 \\
8 & Grajagan & 30 & 30 & 30 & 30 & 120 & 6 & 720 \\
9 & Kedungringin & - & - & - & - & - & & - \\
10 & Kalipait & - & - & - & - & - & & - \\
11 & Purwoasri & - & - & - & - & - & & - \\
12 & Purwoagung & - & - & - & - & & & - \\
\hline
\end{tabular}

Information: 1 . The uniqueness of natural resources; 2 . type of activity or tourism activity; 3 . the cleanliness of the tourist attraction does not influence from; 4. infrastructure

The results of the assessment of tourism potential data and field analysis illustrate that the potential for tourism objects in the TNAP buffer village is in the form of natural beauty, both forest and beach tourism objects, diversity of flora and fauna, religious tourism, arts, and ceremonies or customs and cultural heritage. According to Nugroho et al. (2016); Nugroho et al. (2018); Adikampana et al. (2017) that cultural activities, traditions or village life, and natural beauty are services that can be packaged as rural tourism products that attract tourists to visit. The potential for ODTW in buffer villages is mainly in the form of forests, namely mangrove forests. The region of mangrove forests in the buffer TNAP village is in the Segara Anak and Pang-Pang Bay. Mangrove forest located in Pang-Pang Bay is a mangrove forest designated by the Ministry of Environment and Forestry (KLHK, 2018) as an Essential Ecosystem Area (KEE) with management that pays attention to environmental aspects and improves community welfare (BBKSDA East Java, 2018). The development of a buffer village that can accommodate all of these things is one of them by utilizing the potential of existing resources by being developed into tourism. This is mandated in the Pang-Pang Bay KEE development plan.

\section{Accessibility}

Accessibility is a factor that influences and makes it easier for tourists to carry out tourism activities towards a tourist attraction (Yuniarti et al., 2018). Accessibility factors are very important in encouraging the marketing and development of a tourist attraction and accessibility factors include road conditions, distance, and travel time from the city center. An assessment of the accessibility component in the buffer villages is presented in Table 4.

Based on the results of the analysis, the accessibility factor is classified as moderate but needs to be improved in a good way because in some parts there are damaged conditions. Accessibility to the buffer village at this time, the condition of the road is paved and quite good, but on some roads, the condition has 
been damaged, the damage is moderate or even severe. The journey from the city center to the buffer village can be reached by private vehicle and public transportation with a travel time of 1-1.5 hours. Traveling using public transportation is currently quite difficult due to the limited number of available transportations and departure times which are only a few times a day so that many tourists who come use private vehicles or rent vehicles. The existing accessibility in the buffer village illustrates that currently, it needs improvement and improvement so that it can support tourism development. According to Bonto et al. (2020), inadequate accessibility will affect tourist interest, where low/minimal accessibility conditions will cause lower tourist interest to visit a tourist attraction.

Table 4 Assessment of accessibility components

\begin{tabular}{lllcccccc}
\hline \multirow{2}{*}{ No } & \multirow{2}{*}{ Village } & \multicolumn{7}{c}{ Elements of Accessibility Assessment } \\
\cline { 3 - 8 } & 1 & 2 & 3 & 4 & Score & Weight & Total \\
\hline 1 & Wringinputih & 25 & 25 & 15 & 15 & 90 & 5 & 450 \\
2 & Kedungrejo & 30 & 25 & 15 & 25 & 95 & 5 & 475 \\
3 & Kedungasri & 20 & 20 & 15 & 25 & 80 & 5 & 400 \\
4 & Kedunggebang & 25 & 25 & 15 & 25 & 90 & 5 & 450 \\
5 & Kedungwungu & 30 & 25 & 15 & 25 & 95 & 5 & 475 \\
6 & Kendalrejo & 20 & 20 & 15 & 25 & 80 & 5 & 400 \\
7 & Sumberasri & 25 & 25 & 15 & 25 & 90 & 5 & 450 \\
8 & Grajagan & 20 & 25 & 15 & 25 & 85 & 5 & 425 \\
9 & Kedungringin & - & - & - & - & - & & - \\
10 & Kalipait & - & - & - & - & - & & - \\
11 & Purwoasri & - & - & - & - & - & & - \\
12 & Purwoagung & - & - & - & - & & & - \\
\hline
\end{tabular}

Information : 1 . Road condition; 2. road type; 3 . distance from city center; 4. travelling time

\section{Supporting Facilities and Infrastructure}

Tourism development does not only focus on tourist attractions but also needs tourism supporting facilities. Tourism supporting infrastructure is one of the factors to support tourism development to optimize the potential of tourism objects in the buffer village and can have an impact on the sustainability of tourism objects. According to Yuniarti et al. (2018), the development of tourism potential or attractiveness needs to be followed by good development and management and supported by the availability of adequate tourism supporting infrastructure. This is because tourists who visit not only enjoy tourist attractions but also have the desire to enjoy facilities that can provide satisfaction. Travel supporting infrastructure includes accommodation and number of rooms, restaurants, financial infrastructure, and health infrastructure. An assessment of the components of tourism supporting infrastructure in the buffer village is presented in Table 5.

The results of the assessment of tourism supporting facilities and infrastructure in the buffer village are in good category and their availability is good and adequate so that they are feasible to be developed. The availability of tourism supporting infrastructure is quite good, but some are damaged so that they need repairs and improvements to support tourism development. Additionally, assessment of the property to support the development of rural tourism in the buffer including category low is because the existence of the inn is still concentrated in the city center. The lack of availability of accommodation in the buffer village can be directed to the development of lodging by utilizing community houses. The utilization of community houses as lodging can improve the community's economy and absorb labor and provide experiences for tourists to get to know community culture and people's daily lives. According to Yuniarti et al. (2018), the availability of supporting infrastructure can trigger tourists' interest to visit. The availability of infrastructure 
must be adjusted to the needs of visitors to provide satisfaction to tourists. According to Khotimah et al. (2017), the development of a tourist destination must pay attention to the $3 \mathrm{~A}$ aspects, namely accessibility, amenities, and supporting facilities. The availability of these $3 \mathrm{~A}$ aspects can be used as a reference to measure the quality of a tourist destination.

Table 1 Assessment of tourism supporting infrastructure components

\begin{tabular}{llccccccc}
\hline \multirow{2}{*}{ No } & \multirow{2}{*}{ Village } & \multicolumn{7}{c}{ Elements of Assessment of Supporting Facilities } \\
\cline { 3 - 8 } & 1 & 2 & 3 & 4 & Score & Weight & Total \\
\hline 1 & Wringinputih & 10 & 10 & 30 & 30 & 80 & 3 & 240 \\
2 & Kedungrejo & 10 & 10 & 30 & 30 & 80 & 3 & 240 \\
3 & Kedungasri & 10 & 10 & 30 & 30 & 80 & 3 & 240 \\
4 & Kedunggebang & 10 & 10 & 30 & 30 & 80 & 3 & 240 \\
5 & Kedungwungu & 10 & 10 & 30 & 30 & 80 & 3 & 240 \\
6 & Kendalrejo & 10 & 10 & 30 & 30 & 80 & 3 & 240 \\
7 & Sumberasri & 10 & 10 & 25 & 30 & 75 & 3 & 225 \\
8 & Grajagan & 10 & 10 & 25 & 30 & 75 & 3 & 225 \\
9 & Kedungringin & - & - & - & - & - & & - \\
10 & Kalipait & - & - & - & - & - & & - \\
11 & Purwoasri & - & - & - & - & - & & - \\
12 & Purwoagung & - & - & - & - & & & - \\
\hline
\end{tabular}

Information: 1. Number of accommodation and room; 2. number of rooms; 3 . facilities; 4. infrastructure

\section{Availability of Clean Water}

Water availability is one of the supporting factors in tourism development and is directly related to tourists as well as basic infrastructure that needs to be considered in tourism development to meet tourist needs. Availability of water in tourism development so that it is always available in sufficient quantity and quality to meet current and future needs. An assessment of the component of clean water availability for tourism development in the buffer village is presented in Table 6.

Table 6 Assessment of clean water availability components

\begin{tabular}{clccccccc}
\hline \multirow{2}{*}{ No } & \multirow{2}{*}{ Village } & \multicolumn{7}{c}{ Elements of Clean Water Assessment } \\
\cline { 3 - 8 } & & 1 & 2 & 3 & 4 & Score & Weight & Total \\
\hline 1 & Wringinputih & 25 & 25 & 25 & 30 & 105 & 6 & 630 \\
2 & Kedungrejo & 25 & 25 & 25 & 30 & 105 & 6 & 630 \\
3 & Kedungasri & 25 & 25 & 25 & 30 & 105 & 6 & 630 \\
4 & Kedunggebang & 25 & 25 & 25 & 30 & 105 & 6 & 630 \\
5 & Kedungwungu & 25 & 25 & 25 & 30 & 105 & 6 & 630 \\
6 & Kendalrejo & 25 & 25 & 25 & 30 & 105 & 6 & 630 \\
7 & Sumberasri & 25 & 25 & 25 & 30 & 105 & 6 & 630 \\
8 & Grajagan & 25 & 25 & 25 & 30 & 105 & 6 & 630 \\
9 & Kedungringin & - & - & - & - & - & & - \\
10 & Kalipait & - & - & - & - & - & & - \\
11 & Purwoasri & - & - & - & - & - & & - \\
12 & Purwoagung & - & - & - & - & & & - \\
\hline
\end{tabular}

Information: 1 . Volume; 2. can the water flow; 3 . eligibility for consumption; 4. availability of water 
The results of an assessment of the availability of clean water in villages to support tourism development including category well. The availability of clean water is very much needed in tourism development, both for tourism services and management. The availability of clean water in the buffer village comes from community wells, but its use requires simple treatment first, such as cooking, and is easy to drain because it is not too far from the water source. The availability of clean water in the buffer village can affect the development of accommodation facilities that can support tourism activities.

\section{Relationship with Nearby Attractions}

Based on observations in the field, the results of the assessment of the relationship with tourism objects around the buffer village are quite good, because in the surrounding area there are no similar tours and tourism in the buffer village has unique and unique tourist objects. Village tourism development in the buffer needs to pay attention to the existence of similar attractions around so that the tourism potential of each of men supports the development of tourism in the region TNAP. According to Purwanto et al. (2014), the success of tourism development is also determined by competition between similar tourist objects. For this reason, it is necessary to plan how to build tourism in buffer villages so that they can optimally utilize existing resources. Based on field observations, tourism development plans in buffer villages that need to be carried out currently include structuring tourist attraction areas, adding tourism supporting facilities, improving accessibility and modes of transportation, and increasing tourism attraction promotions. In addition, increasing the capacity of human resources (HR) involved in tourism management so that it can give a different impression to attract tourists to visit. The tourism development plan can be carried out with various programs by collaborating with related parties such as BAPPEDA, Culture and Tourism Office, Transportation Service, Fisheries and Marine Service, and Balai TNAP. Cooperation can be done by providing assistance to the community and Pokdarwis and facilitating the development of tourism infrastructure. The community and Pokdarwis need to be supported with skills and competencies regarding tourism management so that tourism potential is developed optimally and can increase tourist visits. Tourism development in the buffer village is expected to be able to maintain the integrity and sustainability of the conservation area and can meet the interests of the community.

The success of developing TNAP tourism and supporting villages is highly dependent on the level of support provided by the community. According to MacKinnon et al. (1990), the community views protected and conserved areas as a barrier to economic improvement, so that people still carry out activities in the area. For this reason, a collaboration between the community and area managers is needed to have a positive impact on the community's economy. The positive impact felt by the community will encourage community support for the preservation of the TNAP area and tourism development. Moreover, Developing rural tourism in the buffer is expected to reduce the threat posed by the activities carried out by society.

\section{Analysis of Public Perceptions of Tourism Development}

Tourism development must provide space for people living around tourist objects to participate in tourism. Community perception analysis was conducted to determine community participation in tourism development. Community participation is a development management system in villages and rural areas in tourism development by prioritizing togetherness, kinship, and cooperation (Nurman, 2017). Community participation is important because it illustrates how much community support there is for tourism development and an opportunity for community empowerment in activities directly related to tourism and reducing conflicts that may occur in the future. Community participation in tourism development is an ongoing process to realize more prosperous community life (Izwar, 2017). The results of the assessment of community perceptions in the buffer villages towards tourism development are presented in Table 7. 
Table 7 The results of the assessment of the perception of the village community supporting the TNAP on tourism development

\begin{tabular}{llcccc}
\hline \multirow{2}{*}{ No } & Category & Score & $\begin{array}{c}\text { Average Number } \\
(\text { Person })^{\mathrm{a}}\end{array}$ & Total Score & $\begin{array}{c}\text { Average } \\
\text { Score }\end{array}$ \\
\cline { 3 - 6 } & & $\mathrm{a}$ & $\mathrm{b}$ & $\mathrm{c}=\mathrm{b} \times 10^{\mathrm{b}}$ & $\mathrm{d}=\mathrm{a} \times \mathrm{c} / 100^{\mathrm{c}}$ \\
\hline 1 & Strongly agree & 4 & 30 & 300 & 15.05 \\
2 & Agree & 3 & 41 & 410 & 16.45 \\
3 & Doubtful & 2 & 14 & 140 & 4.21 \\
4 & Less agree & 1 & 2 & 130 & 2.61 \\
5 & Strongly disagree & 100 & 1000 & 0.20 \\
\hline \multicolumn{1}{r}{ Amount } & & 100 & 39 \\
\hline
\end{tabular}

Information: ${ }^{\text {a) }}$ The average number of respondents; ${ }^{\mathrm{b})}$ total questions; ${ }^{\mathrm{c})}$ total respondents; scale: strongly agree : 43-50; agree: 35-42; doubtful: 27-34; less agree: 19-26; strongly disagree: 10-18

The results of assessing the rural community's perception TNAP buffer against the development of tourism has a mean score of 39 . This analysis showed that the community agrees to tourism development in the village of the buffer. Community support for tourism development is influenced by the buffer village area, which has natural potential and cultural diversity that can be developed as a tourist attraction. In addition, the results of the overall community perception assessment show that the community agrees and supports tourism development. However, the community is still hesitant and has not supported tourism development in the buffer village. People who feel they have not been able to support tourism development are due to the lack of community ability in mastering foreign languages, lack of knowledge and experience in tourism services and management, and the lack of community skills in making crafts or souvenirs for souvenirs. Based on this, the necessary training and assistance to the community to support Developing travel through cooperation with relevant parties.

Tourism development cooperation in buffer villages can be done by providing training and assistance to the community, especially Pokdarwis. The community and Pokdarwis need to be supported by being given skills and competency training regarding tourism management so that the tourism potential in the village can be developed optimally. Cooperation in tourism development assistance and the provision of training and competence can be carried out by involving the village and the Balai TNAP, the Culture and Tourism Office, the Maritime Affairs and Fisheries Service, and BAPPEDA of the Banyuwangi Regency. Village parties can play a role in the formation of Pokdarwis and related parties play a role in providing training and mentoring.

The community agreed to tourism development have expectations that are involved in the planning, development, and management of travel and want to be trained to support the development of tourism. Therefore, training is very important because it aims to help the community by improving the community's abilities and skills in tourism management. The development of community-based tourism can develop potential with community abilities that are by developed knowledge to stimulate the growth of trust, independence, and cooperation between communities and improve community skills. Tourism development must be carried out to provide benefits to the community both in terms of economy, social, and environment.

Communities involved in tourism development can provide a positive response in supporting tourism development. According to Sharpley (2014), positive public perceptions encourage people to support tourism development, while negative public perceptions can reduce community participation to support tourism development. The development of tourism in buffer villages and the existence of community support can provide knowledge to the community to preserve the area both in the village and in the TNAP area. The sustainability of the area affects the sustainability of tourism activities that are developed and will later affect the level of community welfare. 
The existence of tourism development in TNAP and buffer villages can foster community business development related to tourism, such as the development of tourism services businesses and other tourism needs businesses. Tourism development that involves the community is an alternative that is expected to be able to encourage economic potential and integrated nature conservation efforts as well as improve and expand community-based business activities which are expected to improve welfare and improve the quality of human resources (Izwar, 2017). Community participation in tourism development will support area conservation and area development efforts and strengthen potential village development that contributes to improving the economy and quality of life of the community (Puspaningrum and Agustina 2014; Budiyah, 2020).

\section{CONCLUSION}

The results of this study indicate that the potential for tourism objects in the TNAP buffer village can be developed and is located in 4 villages with various types of tourism. Developing rural tourism in the buffer needs infrastructure supporting the tour, such as accessibility and accommodation. The community agrees over tourism development, and the public wants to be involved in the development and management of tourism there. The development of tourism in the buffer villages needs training and assistance from the community and Pokdarwis in managing tourism so that tourism development can run optimally.

\section{ACKNOWLEDGMENT}

Thank you very submitted to the Bogor Institute of Agriculture, the National Park Alas Purwo, Banyuwangi regency government, the village government Buffer TNAP who have supported and helped collect data and analysis of field data in this study.

\section{REFERENCES}

[Balai TNAP] Balai Taman Nasional Alas Purwo. 2014. Rencana Induk Pemberdayaan Masyarakat Daerah Penyangga Taman Nasional Alas Purwo. Banyuwangi (ID): Balai Taman Nasional Alas Purwo.

[Balai TNAP] Balai Taman Nasional Alas Purwo. 2015. Rencana Pengelolaan Jangka Panjang Taman Nasional Alas Purwo Tahun 2016-2025. Banyuwangi (ID): Balai Taman Nasional Alas Purwo.

[BBKSDA] Balai Besar Konservasi Sumberdaya Alam Provinsi Jawa Timur. 2018. Pengelolaan kawasan ekosistem esensial teluk pang-pang kabupaten banyuwangi. Workshop Verified Conservation Area (VCA); 2018 Dec 24-25; Jakarta, Indonesia.

[Dirjen PHKA] Direktorat Jenderal Perlindungan Hutan dan Konservasi Alam. 2003. Pedoman Analisis Daerah Operasi Objek dan Daya Tarik Wisata Alam (ADO-ODTWA). Bogor (ID): Direktorat Wisata Alam dan Pemanfaatan Jasa Lingkungan.

[KEMENBUDPAR] Kementerian Kebudayaan dan Pariwisata. 2013. Peraturan Menteri Kebudayaan dan Pariwisata No. PM.18/HM.001/MKP/2011 tentang Pedoman Umum Program Nasional Pemberdayaan Masyarakat (PNPM) Mandiri Pariwisata Melalui Desa Wisata. Jakarta (ID): Kementerian Kebudayaan dan Pariwisata.

[KLHK] Kementerian Lingkungan Hidup dan Kehutanan. 2017. Peraturan Menteri Lingkungan Hidup dan Kehutanan No. 43 Tahun 2017 Tentang Pemberdayaan Masyarakat di Sekitar Kawasan Suaka Alam dan Kawasan Pelestarian Alam. Jakarta (ID): Kementerian Lingkungan Hidup dan Kehutanan.

[PKB] Pemerintah Kabupaten Banyuwangi. 2016. Rencana Pembangunan Jangka Menengah Kabupaten Banyuwangi 2016-2021. Banyuwangi (ID): Sekretariat Daerah Kabupaten Banyuwangi.

[PKB] Pemerintah Kabupaten Banyuwangi. 2017. Salinan Peraturan Daerah Kabupaten Banyuwangi No.1 Tahun 2017 tentang Desa Wisata. Banyuwangi (ID): Sekretariat Daerah Kabupaten Banyuwangi. 
Adikampana IM, Sunarta IN, Negara IMK. 2017. Arahan produk pariwisata berbasis masyarakat lokal di wilayah pedesaan. Jurnal IPTA. 5(2): 92-101.

Arikunto S. 2006. Prosedur Penelitian. Ed ke-4. Yogyakarta (ID): Penerbit Rineka Cipta.

Bonto AZL, Rofiaty, Susilowati C. 2020. Pengembangan wisata pantai di Kabupaten Buton Tengah (Studi pada Mutiara, Wantopi dan Katembe). Journal of Natural Resources and Enviromental Management. 10(3): 436-445. doi: 10.29244/jpsl.10.3.436-445.

Buditiawan K, Harmono. 2020. Strategi pengembangan destinasi pariwisata Kabupaten Jember. Jurnal Kebijakan Pembangunan. 15(1): 37-50. doi: 10.47441/jkp.v15i1.50.

Budiyah F. 2020. Implikasi pengembangan desa wisata terhadap peningkatan ekonomi masyarakat lokal studi di Desa Ketenger. JEBA. 22(2): 182-190.

Hamzah AS, Irfan M. 2018. Local wisdom based tourist village Sade Lombok organization within the framework of sustainable tourist development. Adv Soc Sci Edu Humanit Res. 282: 129-132. doi: 10.2991/icblt-18.2018.31.

Izwar. 2017. Persepsi pengunjung ekowisata Pulau Reusam terhadap pengembangan masyarakat pengelola kawasan ekowisata dalam rangka pengembangan kawasan ekowisata secara berkelanjutan. Jurnal Bionatural. 4(1): 1-12.

Khotimah K, Wilopo, Hakim L. 2017. Strategi pengembangan destinasi pariwisata budaya (studi kasus pada Kawasan Situs Trowulan sebagai pariwisata budaya unggulan Kabupaten Mojokerto. Jurnal Administrasi Bisnis. 41(1): 56-65.

MacKinnon J, MacKinnon K, Child G, Thorsell J. 1990. Pengelolaan Kawasan yang Dilindungi di Daerah Tropika. Amir HH, ed. Yogyakarta (ID): Gadjah Mada University Press. Translate from: Managing Protected Areas In The Tropics.

Nugroho I, Negara PD, Yuniar HR. 2018. The planning and the development of the ecotourism and tourism village in Indonesia: a policy review. Journal of Socioeconomics and Development. 1(1): 43-51.

Nugroho I, Pramukanto FH, Negara PD, Purnomowati W, Wulandari W. 2016. Promoting the rural development through the ecotourism activities in Indonesia. American Journal of Tourism Management. 5(1): 9-18.

Nurman N. 2017. Program pelestarian dan nilai ekonomis rumah adat masyarakat Osing. Indonesian Journal of Islamic Economics and Business. 2(2): 43-57.

Prameswari DR, Ardhyanto A, Kusuma HE. 2018. Korespondensi motivasi pengunjung dan karakteristik desa wisata. Jurnal Lingkungan Binaan Indonesia. 7(1): 24-31.

Purwanto S, Syaufina L, Gunawan A. 2014. Kajian potensi dan daya dukung Taman Wisata Alam Bukit Kelam untuk strategi pengembangan ekowisata. Jurnal Pengelolaan Sumberdaya Alam dan Lingkungan. 4(2): 119-125. doi: 10.29244/jpsl.4.2.119.

Puspaningrum D, Agustina T. 2014. Model pembangunan alternatif berbasis masyarakat pada Taman Nasional Meru Betiri. Agritrop Jurnal Ilmu-Ilmu Pertanian. 12(2): 188-199.

Sharpley R. 2014. Host perception of tourism: a review of the research. Tourism Management. 42: 37-49.

Yuniarti E, Soekmadi R, Arifin HS, Noorachmat BP. 2018. Analisis potensi ekowisata Heart of Borneo di Taman Nasional Betung Karihun dan Danau Sentarum Kabupaten Kapuas Hulu. Jurnal Pengelolaan Sumberdaya Alam dan Lingkungan. 8(1): 44-54. doi: 10.29244/jpsl.8.1.44-54. 